\title{
Cape Indians, Apartheid and Higher Education
}

\author{
Uma Dhupelia-Mesthrie* \\ University of the Western Cape \\ umesthrie@uwc.ac.za
}

\section{Introduction}

On a Sunday afternoon, 15 November 2009, the Luxurama Theatre in Wynberg was filled to capacity as Indians in Cape Town gathered to launch the Cape Town 1860 Legacy Foundation in preparation for the 2010 events commemorating the $150^{\text {th }}$ anniversary of the arrival of Indians in Natal. The Foundation had been constituted after meetings in Cape Town had been addressed by Satish Dhupelia and AV Mohammed who were members of the 1860 Legacy Foundation of Durban, tasked with co-ordinating a national movement. They and Ashwin Trikamjee, a religious leader who chaired the Durban committee were present. The gathering brought Gujarati Hindus, Christians, Muslims, and Tamil Hindus of the city together. While the ancestors of many of those present had come as immigrants to the Cape directly from India and had little direct connection to indenture, the Tamils present did have their roots in the indenture system. The movement from Natal to the Cape Colony by the ex-indentured had, in fact, begun from the 1870 s in response to the discovery of diamonds in Kimberley. ${ }^{1}$ Many Tamil Indians would continue to come to the Cape in the post-Union period often breaking inter-provincial restrictions on movement and settling in the Cape illegally.

That day, speakers like CV Nair, an honorary president of the Cape Tamil Federation spoke about his family and the broader context of indenture. As one of the speakers I reminded the gathering that in the Cape, it was slaves who were the first to come from India during the Dutch period of rule at the Cape. Also, while Natal imported indentured labour, the government of the Cape Colony refused to follow suit (despite requests from local employers of labour) because they did not wish to be burdened by the rules and regulations

\footnotetext{
*This research was supported by the National Research Foundation and the Senate Research Committee of the University of the Western Cape. Omar Badsha must be thanked for his incisive comments. Goolam Vahed is always a generous soul and sent me useful readings.

1 Surendra Bhana and Joy Brain, Setting Down Roots: Indian Migrants in South Africa, 1860-1911 (Johannesburg: Witwatersrand University Press, 1980), 100.
} 
issued by the British Government of India. ${ }^{2}$ I then drew attention to the life history of Changen Poonsamy Naidoo, the grandfather of Rylands resident Savimba Moonsamy. An indentured worker in Natal, he made his way to the Cape in later years selling baskets and flowers. I also paid tribute to former waiter, Eddie Nair's, grandparents who were indentured. Eddie, now long-settled in Cape Town, had made the effort to secure his grandmother Minachee's indentured number and found out that she arrived in October 1890 on the Pongola and worked on the Natal Government Railways. The intention was to mark out points of disjuncture from the history of Natal Indians yet to also signify the relevance of the commemorations.

While the gathering underlined a strong identification with the up-coming commemorations and signalled a moment of Indianness, it was Judge Siraj Desai, one of the speakers, who pointed to the apartheid government's role in fostering 'Indianness'. His grandfather had come out in 1898 from a village in what is today, Maharashtra, to work for one of the biggest merchants of that time in Cape Town, Ebrahim Norodien. The Desai family home was established in the multi-racial neighbourhood of Salt River where Desai's grandfather soon established his own business. This was Judge Desai's defining home ground. He recalled:

... the only Indian people I possibly encountered were those few cornershops around us. I went to the Methodist School in Salt River. Most of the children at school ... [their] parents worked then at the Salt River market and this is the sum social milieu I operated in. And then when I went to the Trafalgar High School and I can't say they weren't any Indians there because I've seen Dr Angelo Pillay and Rachmat Omar ... in the audience. So besides them there were very few others at Trafalgar.

And then the worst of things happened. ... Apartheid was intensified when I matriculated and we had to study at the only Indian university outside of India which was Salisbury Island - Westville as it was later known. And when I got to campus on the first day it was an absolute culture shock. l'd never been in a room with so many Indians before (laughter from audience).

And the worst was to come, you know ... We Cape Indians could not travel freely to Natal [just] as Natal Indians couldn't come freely to the Cape ... I had family in

\footnotetext{
${ }^{2}$ See Uma Dhupelia-Mesthrie, "The Place of India in South African History: Academic Scholarship, Past, Present and Future", South African Historical Journal, 57, 2007, 13-14; Uma Dhupelia-Mesthrie, "The Passenger Indian as Worker: Indian Immigrants in Cape Town in the Early Twentieth Century", African Studies, 68, 1. April 2009, 118-9.
} 
Durban and I ... visited on frequent occasions but we ignored the permit rule ... And when I got to university I discovered I couldn't register and the simple reason I couldn't register was this that I was a foreign Indian in Durban. I had to go back to Cape Town and get a permit at the ... Immigration Offices here in Queen Victoria Street. But I tell you the story for one reason alone and the reason is this: that the irony is that the office I used to go [to] is today part of the complex in which I preside as a judge. And every day when I walk pass I tell my colleagues you reside in a court [where at the] bottom of our court, in the foyer, I had to come every year to fetch a permit, [the] absolute limit of indignity. ${ }^{3}$

This story highlights the importance of neighbourhood in Judge Desai's upbringing, a neighbourhood with a predominantly working class population of coloureds and poor whites sprinkled among whom were his family. All his schooling was among coloured children. Apartheid contributed to the enforced making of Indianness. The forced gathering of Indian students at Salisbury Island and later, the University of Durban-Westville, was a novel experience for Cape Indian youth. There were significant barriers to movement between Natal and the Cape ${ }^{4}$ which apartheid enforced yet also relaxed by permits for this new apartheid higher education project unfolding in Durban.

Judge Desai's recollection at this event was all the more appropriate for it was in the month of the centenary commemorations of the arrival of Indians to Natal that the state established the University College for Indians in Durban. ${ }^{5}$ Judge Desai's narrative provides a useful prompt to explore the history and social identity of Cape Indians, the impact of apartheid on this and the experiences of Indian students from the Cape after the passage of the ironically named Extension of University Act (Act 45 of 1959). It draws on the life histories of seven individuals. ${ }^{6}$ These form part of a bigger project to document the history of Indians in Cape Town. The narratives have been selected to indicate a diversity of responses to apartheid university education and represent an early generation of university graduates. Two interviewees went to the University College for Indians at Salisbury Island while one went to the University of Durban-Westville. The inclusion of the latter is significant for it represents a time when the fledgling project begun at Salisbury had become

\footnotetext{
${ }^{3}$ This speech was transcribed from a video recording of the event made by Channel 4 Productions in Cape Town.

${ }^{4}$ There interprovincial restrictions date back to the early years of the $20^{\text {th }}$ century.

${ }^{5}$ GC Oosthuizen, AA Clifford-Vaughan, AL Behr and GA Rauche (eds), Challenge to a South African University: the University of Durban-Westville (Cape Town: Oxford University Press, 1981), 32.

${ }^{6}$ All interviewees have given permission for the use of their names.
} 
fuller and complete. The article also highlights the experiences of four others who avoided Durban by studying through the University of South Africa (UNISA) through the South African Committee for Higher Education (SACHED), or going overseas or securing a permit for study at the University of Cape Town (UCT). How different were their experiences from those who went to the university for Indians and does it set up a 'them' versus 'us' scenario? Female experiences are highlighted for five of the seven interviewees are women. The life histories point to early schooling, places of residence, the experience of tertiary education and work opportunities thereafter and allow one to assess the impact of the Extension of University Act of 1959 against the broader canvass of apartheid's spread.

The approach here is a qualitative rather than a quantitative one. Alessandro Portelli has done much to dent the positivist approach to history with its focus on facts and its preference for the written source. He has pointed to the significance of studies of subjectivities and makes the important point that "there are no 'false' oral sources ... 'wrong' statements are still psychologically true ..." The oral historian should focus on the meaning of memories and the nature and form of the narrative. ${ }^{7}$ This article thus focuses on the subjective experiences of individuals and their life stories as told by them. They represent how interviewees see their lives, their past and how they have come to terms with that past.

\section{Cape Indians and Indianness}

Indianness is a very fluid concept: varying over time for the different generations; varying amongst Indians and varying from province to province. Chetty, for instance, has pointed to how the Indianness of the trader who had greater contact with India was different from the Indianness of the indentured worker. ${ }^{8}$ Omar Badsha observes that the Indianness of the early immigrant was hardly the same as the subsequent generations of South African born Indians. ${ }^{9}$ Bhana and Vahed have pointed to the role of the colonial state in fostering

\footnotetext{
${ }^{7}$ A Portelli, The Death of Luigi Trastulli and Other Stories: Form and Meaning in Oral History (New York: State University of New York Press, 1991) 50-53

${ }^{8}$ D Chetty, "Identity, Interpretation and 'Indianness' : Some Stories from the Natal Cane Fields", Paper presented to ASSA Conference, 1991, 4.

${ }^{9}$ Telephone conversation with Omar Badsha, January 2013. Omar must be thanked for pushing me to elaborate the contexts of Indianness.
} 
Indianness by legislating against Indians. ${ }^{10}$ The apartheid state, in particular, did much to create Indianness from the 1960s onwards - divided ethnicities formed the heart of the apartheid project. The creation of a Department of Indian Affairs in 1961, separate group areas, and separate university education were all part of this project. The booming South African economy in the 1960s allowed the state to allocate capital to achieve its goals. Many would fall in line with the government's plans embracing Indianness through separate structures. Others embraced black consciousness in the 1970s and rejected such narrow identities. In the democratic era, however, under the umbrella of the idea of the 'rainbow nation', Indianness found fertile ground to flower. Jay Naidoo, after years of rejecting his Indianness, began to explore this during a visit to India. Ela Gandhi cautioned that for her "Indianness comes in at the level of culture ... [but] that is where the Indianness stops". ${ }^{11}$ The commemorations of the 1860 pioneers would prompt more outpourings of Indianness in the context of history and heritage. ${ }^{12}$ Given the complexities, this section offers just a few important points in its consideration of Cape Indians and Indianness and elaborates on differences between the Cape and Natal.

On the eve of apartheid, unlike Natal where over $80 \%$ of Indians in South Africa lived, only $5 \%$ lived in the Cape. This had been the pattern of population distribution since the early years of the twentieth century, though by 1980 the percentage would dip to $3.9 \% .{ }^{13}$ This has some implications for how Indians in the Cape were treated. Unlike Natal where numbers became of political significance since Indians exceeded the white population, Indians would always be the minority in the Cape. In the Cape Peninsula, for instance, in 1960, Indians constituted just $1.13 \%$ of the total population and this did not change much

\footnotetext{
${ }^{10}$ This is fully explored in Surendra Bhana and Goolam Vahed, The Making of a Political Reformer: Gandhi in South Africa, 1893-1914 (New Delhi: Manohar Publishers, 2005), introduction, chapter 1, conclusion.

${ }^{11}$ See Uma Dhupelia-Mesthrie, From Cane Fields to Freedom: A Chronicle of Indian South African Life (Cape Town: Kwela Books, 2000), 9, 27.

12 For several essays on the commemorations see Rehana Vally, "Made in India, Proudly South African: Commemorating 150 years of Indian Presence in South Africa" and Brij Maharaj, "Commemoration, Celebration or Commiseration? $150^{\text {th }}$ Anniversary of Indentured Labourers in South Africa" in Sugata Patel and Tina Uys (eds), Contemporary India and South Africa: Legacies, Identities, Dilemmas (New Delhi: Routledge, 2012), 65-95; Rajend Mesthrie, "Public Lecture series on 150 Years of Indian History in South Africa", Social Dynamics: a Journal of African Studies, 37, 3, 2011, 436-38 and Omar Badsha and Jon Soske, "150 Anniversary. Anxieties of Commemoration -Towards a National Dialogue", 18 April 2010 at historymatters.co.za.

${ }^{13}$ P Brijlal, "Demographic Profile" as well as Antony Arkin, "Economic Structure" in AJ Arkin, KP Magyar, GJ Pillay (eds), The Indian South Africans : A Contemporary Profile (Pinetown: Owen Burgess, 1989), $27,56$.
} 
over the next four decades. ${ }^{14}$ Unlike Natal, where from the beginning there were separate laws and also separate administrative structures for Indians because of the indenture system, there was nothing like this in the Cape.

From the earliest years, missionaries and government established separate schools for Indians in Natal, an example followed by Indians themselves in later years. In contrast, there were no separate Indian schools in the Cape. ${ }^{15} \mathrm{Dr}$ Mahate, a community historian, comments that Cape Indians were at an "advantage" in comparison to Natal where "there wasn't the intermixing between the so-called Africans, coloured and Indians at the school level which we had here." ${ }^{16}$ If Indians did build schools for themselves these were Muslim rather than purely Indian schools. ${ }^{17}$ Madrassas for religious instruction were also built and Gujarati Hindus established the Gandhi Memorial School in 1947 for afternoon classes in Gujarati.

Natal University College (which became the University of Natal in 1950) also first declined admission to black students, and then instituted separate classes in separate venues in 1936, a system that endured till the University College for Indians was established. ${ }^{18}$ In comparison, UCT accepted blacks into common classes. Yet as Howard Phillips has pointed out white administrators and white students were racially prejudiced; the former set limits to the full inclusion of black students to all courses and did not seek to encourage numbers. ${ }^{19}$ Black students did suffer discrimination and as Bank has argued lived "on the margins of university life." ${ }^{20}$ Despite this it would be true to say that there was nothing like the Natal system.

\footnotetext{
${ }^{14} \mathrm{CM}$ Brand, "Solidarity Patterns in a Minority Group: A study of the Indian Community of the Cape Peninsula" (unpublished MA, University of Stellenbosch, 1966), 62, 77; Uma Dhupelia-Mesthrie, "Gujarati Shoemakers in Twentieth-Century Cape Town: Family, Gender, Caste and Community", Journal of Southern African Studies, Vol.38, No.1, March 2012, 168.

${ }^{15}$ See SR Maharaj, "Primary and Secondary Education" in Bridglal Pachai (ed.), South Africa's Indians the Evolution of a Minority (Washington: University Press of America, 1979), 338, 356.

${ }^{16}$ Interview with Dr Allie Hoosain Mahate (born 1932) by Uma Dhupelia-Mesthrie, 17 December 2009.

${ }^{17}$ The Habibia Primary School, for instance, opened in 1946 but it catered for Indian Muslims and Malays. See Habibia Primary School 1946-1996: $50^{\text {th }}$ Anniversary Magazine.

${ }^{18}$ This has been well documented in Surendra Bhana and Goolam Vahed, "Colours Do Not Mix": Segregated Classes at the University of Natal, 1936-1959", Journal of Natal and Zulu History, Vol. 29, 2011, 66-100.

${ }^{19}$ See Howard Phillips, The University of Cape Town 1918-1948: The Formative Years (Cape Town: University of Cape Town and University of Cape Town Press, 1991), 114, 192-3, 225-6, 233-34.

${ }^{20}$ See Andrew Bank, Archie Mafeje: the Life and Work of an African Anthropologist (1936-2007) (Alice: Fort
} 
By the 1940s, Indians in Cape Town had not congregated in any "ethnic quarters". ${ }^{21}$ They lived throughout Cape Town in the major areas of District Six, Mowbray, Claremont, Newlands, Wynberg, Salt River, Observatory, Rondebosch, Black River, Parow, Goodwood, Belville and Simonstown to mention a few. Their neighbourhoods shaped them and they would have strong identities as Claremont people or Black River people, for example, and their friends were drawn from the coloured and Malay people among whom they lived. ${ }^{22}$ Indians, like other blacks, could also exercise the franchise in the Cape if they met the property and education qualifications. Some even became city councillors, Councillor Ahmed Ismail being one such person.

Lest one paint an over glamorous picture of the life of Indians in the Cape, Vivian Bickford Smith has pointed out how social segregation between those white and those not white marked the city at the turn of the twentieth century in mission schools, hospitals, prisons and asylums and he cautions one about the "myth of a pre-Apartheid golden age in Cape Town's history", though this is the perspective of many black residents of the city. ${ }^{23}$ Recent work has also shown how Indians became the target of restrictive immigration policies from 1902 onwards which effectively excluded fresh immigration and subjected the resident Indian population who wished to travel abroad to humiliating identity documents which bore their photographs and thumbprints. ${ }^{24}$ There was some residential segregation locations for Africans; separate municipal housing schemes for whites and coloureds; some segregated private white housing schemes and, in some areas, whites also inserted restrictions in their title deeds to prevent sale to people of other races. A survey in 1936

\footnotetext{
Hare University Press, 2010), 17; Ciraj Rassool, “A Full Circle: Concerning UWC's Academic Value" in Premesh Lalu and Noeleen Murray (eds) Becoming UWC: Reflections, Pathways and Unlacing Apartheid's Legacy (Belville: Centre for Humanities Research, 2012), 86; and Bhana and Vahed, "Colours Do Not Mix", 74.

${ }^{21}$ Peter Scott, "Cape Town: Multi-Racial City", The Geographical Journal, No.121, 1955, 154-55.

${ }^{22}$ See, for instance, Wiesahl Taliep, "A Study in the History of Claremont and the Impact of the Group Areas Act circa 1950-1970" (unpublished BA Hons essay, UCT, 1992) and Uma Dhupelia-Mesthrie, "Dispossession and Memory : the Black River Community of Cape Town", Oral History, Autumn 2000, Vol. 28, No.2, 35-43.

${ }^{23}$ See Vivian Bickford-Smith, Ethnic Pride and Racial Prejudice in Victorian Cape Town: Group Identity and Social Practice, 1875-1902 (Cambridge; Cambridge University Press, 1995), 2; Vivian Bickford-Smith “ 'A Special Tradition of Multiracialism?' Segregation in Cape Town in the Late Nineteenth and early Twentieth Centuries", in Wilmot G James and Mary Simons, The Angry Divide: Social and Economic History of the Western Cape (Cape Town: David Philip, 1989), 47ff; Vivian Bickford-Smith, "South African Urban History, Racial Segregation and the Unique Case of Cape Town", Journal of Southern African Studies, Vol. 21. No.1, March 1995, 63-78.

${ }^{24}$ See Dhupelia-Mesthrie, "The Passenger Indian as Worker", 115-120.
} 
found that $62 \%$ of white Capetonians lived in what could be regarded as white zones while $51 \%$ lived in "Non-European zones." Within some predominantly white zones, they could be many pockets occupied by Indians, Malays and coloureds. ${ }^{25}$ While this is so, the main point is that Indians were not separated from the more numerous coloureds and Malays of the city and those who were affluent could also live where they wished.

In terms of marriages too - while many Indians would start bringing out wives from India particularly from the 1920 s onwards, given the similarity of their religion Indian Muslims married Malay women, a pattern developed from early days. As one politician married to a Malay woman said of his family: "if we come outside our door you may think we are Cape people. ${ }^{26}$ There were those Hindus and Muslims who also married local coloured women. ${ }^{27}$ Dr Mahate points out that in the coloured townships one would find many Naidoos and Pillays and, similarly, if one went to the Muslim graveyards one will find some Naidoos for some converted after marrying Malay women. ${ }^{28}$ Indian Muslims also spoke Afrikaans at home.

In the 1960s, Brand sought to answer the question: "to what extent do the Indians of the Cape Peninsula feel themselves to be part of the total South African Indian community?" His conclusion was that while there were links along religious, linguistic and caste lines an ethnic identity as a South African Indian was not strong at all. ${ }^{29}$ Gujarati Hindus had several caste organisations and they established links with other caste members in other parts of South Africa. They also constituted the United Hindu Association (formed 1903) which organised religious and cultural functions and managed the Gujarati School. Indian Muslims, especially those originating from the Konkan areas in Maharashtra, established village

\footnotetext{
${ }^{25}$ Scott, "Cape Town: A Multi-Racial City", 151-55.

26 SC9-26, Report of the Select Committee on the Subject of Areas Reservation and Immigration and Registration (Further Provision) Bill, 462. The speaker was Burhamoodien Desai of the Cape British Indian Union.

${ }^{27}$ See Uma Dhupelia-Mesthrie, "Wives of Indian Immigrants in Twentieth Century Cape Town: Stories of Stasis, Mobility and Settlement, 1900s to 1940s", Paper presented to the International Social History Conference, University of Brighton, April 2012.

${ }^{28}$ Interview with Dr Mahate, 17 December 2009.

${ }^{29}$ Brand, "Solidarity Patterns", 90-91.
} 
societies to provide cohesive activity for those in Cape Town and also to uplift the village in India. ${ }^{30}$

Political affiliations are more complex. There were some Indians who felt the need to organise and belong to separate Indian organisations from the early years of the twentieth century and there was affiliation to the South African Indian Congress (SAIC) since its establishment in 1927. Councillor Ismail was, in fact, president of the SAIC in the mid-1940s. There was also affiliation to the short lived South African Indian Federation (formed 1927). While this is so, several Indians would also be attracted to the Non-European Unity Movement (formed 1943). The young Koknie Moslem League, for instance, attended the 1945 conference of the Non-European Unity Movement (NEUM) in Cape Town. ${ }^{31}$ Dullah Omar was a prominent member of the NEUM in the 1950s and 1960s. Several Indians were also associated with the Coloured People's Congress.

Apartheid impacted on Indians in the Cape in significant ways: firstly, there was classification in terms of the Population Registration Act and Group Areas Act of 1950. The fluid relations and boundaries between Indians, Malays and coloureds were now subject to hard classification. It is well-known that classification brought immense hardships for coloureds, families being split by those who succeeded in passing for white and others unable to do so. It would be a mistake to assume that Indians who were classified faced no difficulties or that this was an easier process and that being Indian was self-evident. Several descendants of Indian and coloured parents took a coloured identity, and many only now are coming to terms with their Indian roots. ${ }^{32}$ Those with a Malay parent took on a Malay identity. Escaping classification as Indian was the desired goal of most Indians and some

\footnotetext{
${ }^{30}$ See Uma Dhupelia-Mesthrie, "Gujarati Shoemakers in Twentieth-Century Cape Town" 175-81. The UHA survived right into the 1970s when it was replaced by the Cape Hindu Cultural Society in 1973.

${ }^{31}$ Among the Indian political organisations in the Cape between 1900s and 1940s were: the British Indian League, South African Indian Association, the Cape British Indian Union, Cape British Indian Council, United Cape Indian Association, Cape Indian Congress, the Cape Indian Association. The Colonial Born Indians Association (Cape Province), Indian National Association, Cape Indian Congress. See Appendix 4 for political organisations and their membership in Uma S. Mesthrie, '"From Sastri to Deshmukh: A Study of the Role of the Government of India's representative in South Africa, 1927 to 1946"( Unpublished PhD, University of Natal, 1987), 333ff.

${ }^{32}$ See for example the case of Bareyam Singh's family and that of Harnam Singh in Uma Dhupelia-Mesthrie, "The Passenger Indian as Worker", 126, 128-29; Siona O'Connell explores her links with Bareyam Singh in a moving account in her thesis, "Tonal landscapes: Re-Membering the Interiority of Lives of Apartheid Through the Family Album of the Oppressed" (PhD, University of Cape Town, 2012), 231-37.
} 
managed to be classified Malay "despite being Indian through and through." ${ }^{33}$ For Hindus there was less of an escape. In terms of the Group Areas Act, Indians were allocated just two areas: Rylands in 1957 and a year later, Cravenby. ${ }^{34}$ These were on the Cape Flats and far from the suburbs where Indians had long dwelled. If classification as coloured or Malay was achieved, then access to coloured group areas could be assured. These, given the size of the coloured population, were significantly more than allocated to Indians. Malays had the advantage of being regarded as coloureds for group areas purposes. ${ }^{35}$ It thus became "fashionable" for Indian Muslims to secure a Malay identity especially for business reasons. ${ }^{36}$ Brand observes that the Cape Town magisterial district observed a decline in the number of Indians from the 1951 census to the 1960 census: from 4216 to 3790 and suggests that classification as Malays accounts for this. ${ }^{37}$

The creation of a Department of Indian Affairs in 1961 meant that Cape Indians were for the first time subjected to a separate administration. Relocation to Rylands and Cravenby took place throughout the 1960s and early 1970s. Indian management committees were established here, though these would not be supported by many. Dullah Omar, for instance, led the formation of the Thornhill Residents' Association (TRA, formed 1981) in Rylands which did not even adopt Rylands as its name looking instead to the old name, Dooringhoogte, for inspiration. For the very first time an Indian school was opened in Rylands in 1976 . The community was so incensed by the name Rylands Indian High School that the school had to quickly drop the word Indian and it was ultimately named Rylands Secondary High School. ${ }^{38}$ While segregated schooling came much later, Indians had already begun to feel the impact of the new university taking shape on Salisbury Island in 1961. This was even before relocation to Rylands. The question that one seeks to ask is what was the impact of this on Indians in the Cape?

\footnotetext{
${ }^{33}$ Uma Dhupelia-Mesthrie, "Tales of Urban Restitution, Black River, Rondebosch", Kronos, 32, November 2006, 228

${ }^{34}$ Pelican Park was a late comer in the 1980s.

${ }^{35}$ An all Malay group area was established in the Bo-Kaap but elsewhere in Cape Town they would be grouped with coloureds.

${ }^{36}$ Interview Dr Mahate, 17 December 2009.

${ }^{37}$ Brand, "Solidarity Patterns", 63.

${ }^{38}$ See Interviews with Moses Mathews (born 1950), 19 December 2009 and Derek Moodley (born 1942 ), 22 February 2010, by Uma Dhupelia-Mesthrie.
} 


\section{Durban bound}

At the time the university college was opened in Durban, the number of Indians nationally who had acquired higher education was really quite small, just a thousand. ${ }^{39}$ The announcement of an Indian university was met with dismay and among the reasons against this was a principled opposition to such segregation; a belief that segregated higher education was in fact inferior education and would lead to the entrenchment of racial difference. There was widespread condemnation of the plans. ${ }^{40}$ The site for the college was itself a problem. The institutional history records:

There was hardly a window or window-pane that was not falling to pieces. The asbestos roof was missing in some places, cracked or holed in others, and the grass was about five feet high - indeed a sorry sight. Some members of the Indian community ... had already visited Salisbury Island. What met their eyes must have been enough to shatter any hopes they may have had for a dignified university institution ...

The Island had to be reached by a ferry from Gardiner Street; the longer route via a causeway from a railway station at Fynnland was not practical. ${ }^{41}$ However plans would go ahead. Construction of laboratories, lecture rooms, offices and hostels had to be started so that the first intake could be made in 1961. There were just two Faculties, Arts and Science to start with, though, in 1965, the Faculties of Commerce and Administration and Education were added. Beginning with 114 students, numbers would rise to 973 in 1965 and 1642 in 1970. The first degrees and diplomas totalling ten were awarded in 1964 . This would grow annually: to 50 in 1965, 105 in 1966 and 337 in 1971. Bhana observes that the university grew largely because there was a demand for higher education; because other universities became unavailable due to the law; and because there was "persistence" and "perseverance" from those charged with developing the campus. ${ }^{42}$ While Indians would go to the Indian university out of lack of choice, many would seek permits to the other universities which were granted mainly if courses were not offered at the Indian university or they could study by correspondence though UNISA. Thus the 1642 students attending the Indian university in Durban, represented $48 \%$ of the total number of Indian students at

\footnotetext{
${ }^{39}$ Oosthuizen et al, Challenge to a South African University, 29.

${ }^{40}$ See Surendra Bhana, "University Education" in Pachai (ed.), South Africa's Indians, 411ff. This is the focus of Goolam Vahed's article in this issue.

${ }^{41}$ Oosthuizen et al, Challenge to a South African University, 36-42.

42 Bhana, "University Education", 420-21.
} 
universities, while 347 went to Natal University, 137 to UCT, 300 to Witwatersrand, 40 to Rhodes University and 976 to UNISA. ${ }^{43}$

Manu Dala of Cape Town first tried UCT and then made his way to Salisbury Island in 1966. Manu (born 1945) was the son of a shoe repairer, the second eldest in a family of four children. ${ }^{44}$ He grew up in Claremont, went to St Mathews Primary School in Rosemead Avenue (Kenilworth) and then to Livingstone High School (Claremont) where he completed his matric in 1962. Of his neighbourhood he has this to say:

I could say a lot of good things about Claremont because in those days we weren't politically separated and we all lived in harmony amongst everybody in the neighbourhood and we all went to the same school and the doors to our homes were never closed because all the neighbours would walk in and walk out ... You didn't know race ...

Livingstone High School was inspirational because of the intellectual quality of the teachers. Manu rattles off names among them Allie Fataar, Frank Grammer, Richard Dudley and the principal, Ray Carlier. He recalls teachers like Neville Alexander and Victor Wessels being "picked up in class by the state security police in front of us and locked up ... And that's why I was so against the apartheid system."

On completing matric in 1962, he chose a course not offered at "the bush colleges" and registered initially for mechanical engineering at UCT before switching to chemical engineering. He developed a good camaraderie with his fellow students, who in his third year, numbered eleven, all of whom were white. Manu had no complaints about discrimination, that is until his third year of study when the department sent its students for practical training. All eleven white students were sent to African Explosives and Chemical Industries $(\mathrm{AE \&} \mathrm{Cl})$ in Somerset West. Manu observes:

They would never allow a black guy like me to go there so they offered me a position in Okiep in the Free State ... This ... head of the department obviously didn't know that ... Indians ... were not allowed in the Free State let alone having a permit and I went to the office and I fought and I fought and they wouldn't change their minds ... I asked why I could not go with the rest of the college mates and they refused. They said this is the law and they couldn't change the law. That's when I

\footnotetext{
${ }^{43}$ Oosthuizen et al, Challenge to a South African University, 45,71, 96.

${ }^{44}$ Interview with Manu Dala by Uma Dhupelia-Mesthrie, 9 January 2010; additional clarification by phone, 30 December 2012 and email, 3 January 2012.
} 
packed up, very frustrated, and I left UCT ... So three years of my life was wasted at UCT ... it was against my principles to follow that sort of career where I was going to be branded as black ...

He guesses that at a time when there was the possibility of terrorist activities, training at an explosive and chemical company was not regarded as appropriate for a black student like him. At the time, he pondered that if practicals were such a problem what did the future hold in this line of work? After a six month break in studies, he began afresh arriving at Salisbury Island in 1966 to study for a BSc in pharmacy. First, the permit had to be obtained for travel to Durban "for $25 \mathrm{c}$ you could get an open permit for a year. Nobody ever looked at it but you had to have a permit to be in Durban." Then came the train journey -he remembers that the non-white coach lay directly behind the engine. In Durban he was picked up by friends of the family but, otherwise, he did not really get to know the city. While the degree was a five year programme - the second and third years were practical years and Manu returned to Cape Town to serve an internship, returning in his fourth and fifth years to Salisbury Island.

He secured hostel accommodation counting himself "lucky" since he did not have to spend time travelling. Most of the residents were from the Cape or the Transvaal - they received priority in placing given that they had nowhere else to go to. He points out a limitation: "unfortunately there was no access to town on the weekends because the ferry service closed on Saturday at 5 o'clock and we were on the island till Monday morning ..."

On the conditions in the hostels he says:

The hostel facilities were good if you were a final year student because then you could stay in a room alone or share with one person. The first year students all shared three to a room. We had to do our own laundry. The food was in the cafeteria area. The food was atrocious. Ok, I mean for six people to share one dish of lamb curry. [There] will be two pieces of lamb and four potatoes - that's how you shared it with a lot of water and brown gravy. ... The best meal of the ... week was Friday afternoon -fish and chips. It was the only meal to look forward to. There was nothing else. And if you were vegetarian I think you lived on tomato curry or tomato chutney that was all you had. Maybe now and then you can throw in an egg.

There was no running hot water. We had to go outside in the yard to stoke the fire and when you stoke the fire ten guys would shower and then the water went cold 
and then you went out and you stoking. Whether its summer or winter you did your own stoking and especially over the weekend or the vacs.

He found that their time was quite packed since lectures and practicals kept them busy. But when they had some free time they "played lots of sports. We learnt to play table tennis, tennis, cricket, soccer." There was also a swimming pool.

There would be a small connection for Manu on the island, one that did not register too seriously for I had to ask him about it. In his recollection of the years on Salisbury Island, the Rector SP Olivier made an observation about $\mathrm{AE \& Cl}$ :

For years, Salisbury Island was used by AE\& $\mathrm{Cl}$ to load and export explosives to other countries. This normally took place at weekends, but sometimes the boat could not wait. With students in residence and in classrooms, I considered this very dangerous, so it was agreed that we would send students off the Island whenever we were advised that a trainload of explosives was on its way to be loaded the following morning. The Company generously gave the University an allowance to provide picnic packs for resident students. ... Residence students had to wander about the city, away from their books and study convenience ... When examinations had to be arranged, we were forced to find other venues in the city and once we even rented a restaurant for this purpose. ${ }^{45}$

Manu simply recalls that in 1966 they were given vouchers to spend the day in the city but does not remember it occurring in later years. As for being at Salisbury Island:

Yes, we were all not happy to be there. Firstly there was a University in Cape Town offering pharmacy or whatever you wanted to do but they wouldn't allow us. Already we were angry to get to Durban. Once we got there, the education was ... sub-standard. The accommodation was sub-standard. It wasn't a university atmosphere that I knew at UCT. I tell you there was no history to the buildings. There was no history to the academic life and we felt that we had to qualify and get out as soon as possible. And that's what we did. We just focussed on studying and educating yourself and get what you wanted and get out of there.

Close relationships, however, developed within the hostel:

We had 120 males and 60 females [in the hostel] ... the ratio was 2 to 1 and that was very interesting and being on the scientific side I would do all the calculations and the stats and I knew that the ladies were in demand. ...Yes we had a very very strong unit of students between the boys and the girls and they became like our sisters you can call it that because we were on the island in our own little community.

\footnotetext{
${ }^{45}$ Oosthuizen et al, Challenge to a South African University, 50.
} 
Following his graduation, it was back to Cape Town. He took a position at Ashers Pharmacy in Plumstead, and, as he says, 46 years later he is in the same place albeit now as co-owner of the pharmacy.

Although Manu escaped group areas confinement for business, he could not escape group areas for residence. In 1972, after his marriage, he built his home in Rylands. While he points out the poor facilities in the area such as gravel roads, for him there were two important things about the move to Rylands which he had made reluctantly. He built his home to his own design and, socially, there were advantages of having many friends and family within the same neighbourhood.

Manu's wife is Jasu Govindjee (born 1950). She was originally from Port Elizabeth and they met at Salisbury Island in 1969 after he returned from practicals. ${ }^{46}$ She was a hostel student between 1968 and 1971. The youngest of four children, Jasu attended Southend High School in Port Elizabeth where pupils were mainly coloured and Indian. This was where Dennis Brutus taught. She recalls the detention of many teachers. After she completed her schooling, Southend, which fell in a white group area, was demolished. She notes with regret: "... we don't have a school so we can say that was my school."

Jasu attributes her advancement to university to a progressive father. When her elder sister wanted to study physiotherapy in Durban in 1963 (she was accepted at the University of Natal), he had no qualms about sending her. Jasu elaborates: "Everybody was up in arms because you don't send your daughter to Durban. She's going to be married. She's going to be in the kitchen ... His argument ... [was] that if boys are educated who are they going to marry? We were very fortunate that my father was that way ..." Her account points to general ideas within the Gujarati community at the time that the only vocation for women was to get married so why educate them. Jasu's dad played with that notion and argued that women, even if they did get married, would need an education to match their husbands. Jasu's sister made her path easier as did a brother who also went to Salisbury Island at the same time to acquire a teaching diploma.

\footnotetext{
${ }^{46}$ Interview with Jasu Dala by Uma Dhupelia-Mesthrie, 9 January 2012; additional information by phone, 30 December 2012.
} 
Hostel life posed many difficulties. Firstly, “... the seniors weren't very pleasant with us. They gave us quite a bad initiation ..." For vegetarians, in particular, food posed a major difficulty. Olivier notes from the administrative side they had to cater for four groups: halaal meat for the Muslim students with no pork; meat (but no beef) for Hindu students; vegetarian for others; and some provision for Christian students. Yet he admits that food was a problem at the hostels; the Professor of Physiology had found most of the hostel students to be anaemic and they tried to rectify the diet. ${ }^{47}$

Jasu talks about the strict dress code on the island: ties for male students, for the girls it was stockings and dress. The rector seemed to have an obsession about the dress code, threatening to inspect students at lectures and warning lecturers that they should exclude inappropriately dressed students. Lecturers themselves had to wear graduation gowns. ${ }^{48}$ Jasu, however, notes further restrictions at dinner in the hostels. "We all had to wear the undergraduate gown ... the black gown. We did it for four years." One of the biggest issues for her was that "... at 7.30 our hostel was locked. We had to be in at half past seven at night every day and it's locked in .... Only the girls. That was the security. I think that's the way they told the parents you know that your daughters will be safe."

The overall impression is that of a hugely authoritarian environment that hardly encouraged free thinking. Betty Govinden aptly points out the island "was part of the panoptic structures of surveillance that constituted the apartheid edifice." ${ }^{49}$ Yet Jasu's narrative also points to many survival and support structures that students like her drew on. Her brother was in the male hostel at Salisbury Island and she shared her room with a friend from Port Elizabeth which made things easier. That there were many students from Port Elizabeth helped. However, living with 60 girls in a hostel would present a challenge: "We had our problems, you know girls being girls ... It teaches you a lot. It really made me grow up." In this respect, this is a story that any student away from home experiences. Jasu, had an aunt in Durban and her parents had lots of friends. So every Saturday, there was a trip to Durban

\footnotetext{
${ }^{47}$ Oosthuizen et al, Challenge to a University, 51.

48 Ibid.

${ }^{49}$ Devarakshanam (Betty) Govinden, “Remembering 'Salisbury Island””, Yesterday and Today, No.6, December 2011, 59.
} 
to have lunch. "Most of the times we came back because we had so much work to catch up for Monday." They would use their time in Durban to buy puri patha and other things. Then there were hostel girls from Stanger who went home each weekend bringing back food to share with the others. The girls were allowed to have a stove in their rooms so they could heat up their food or cook occasionally.

On Friday nights the male and female hostel students had a joint social. "So that was nice. We met each other and that was good. Lots of couples came out of that. My brother and his wife got married and Manu and I did and so many of my friends are married from that." The Hindu girls got together to pray together on Saturday evenings. She learnt a lot about Islam from her Muslim friends. This provides a different perspective to that of Olivier who points out how his time was spent arbitrating disputes between students of different persuasions. ${ }^{50}$ Like Manu, Jasu also took to sport and played tennis and table tennis. Her brother, in particular, excelled at sport taking many trophies. While Salisbury Island was to be a place of political activity for many students, Jasu's approach was to study hard: "to get done ... we must pass every year ... It was difficult times." She had a hiccup with her subjects for the BA and was happy when in her second year she switched to Social Sciences with majors in Sociology, Psychology and Social Work. Jasu graduated in 1971 noting that they were the last lot of students to get a UNISA certified degree for, in 1972, the University of Durban-Westville came into being. Graduation was a big issue as many students were protesting the impending new changes. Manu, who also secured a UNISA degree explains that students preferred this as it was "internationally recognised"; unlike a degree from an unknown university being born at Westville. Jasu attended the graduation at the city hall but students boycotted the formal dinner.

In 1972 Jasu and Manu married and she points to difficulties once she started work at Cape Mental Health in Cape Town:

... about five months down the line they called me to say that there's not enough Indian patients for an Indian social worker so they wanted me to go out to Rylands. And I never even know those areas so well to go and find Indian psychiatric patients and it became an issue. And we took it to the top level ... and Cape Mental

\footnotetext{
${ }^{50}$ Oosthuizen et al, Challenge to a University, 51.
} 
Health said they can't do anything because there's not enough patients for me. And I spoke Afrikaans and I could do the coloured patients but they said no.

Jasu left and found a position at a clinic dealing with alcoholics in the coloured group area at Athlone where she worked for a few years till she fell pregnant. Domesticity took over and she brought up three girls. She was, however, active in several organisations in Rylands such as the Vadhini Indian Arts Academy which her children attended. She and other parents raised funds and provided support when the school staged shows. Jasu was secretary of the committee of the newly established Wonderland Pre-Primary (formed 1985) which her daughter attended and a founder member of the Ryland's Homecraft organisation which brought women from the area together to share sewing, knitting, embroidery, cooking and other skills.

Jasu's and Manu's narratives are not tinged with nostalgia in the fashion of Betty Govinden's very poetic essay on Salisbury Island. ${ }^{51}$ Neither are these narratives of political activity which tend to dominate accounts of life at segregated universities for these spaces politicised many. These provide an insight into everyday life experiences and are told in a matter of fact tone. The effect is to show how despite apartheid, despite the humiliating unequal circumstances in which they found themselves, they tried to make the best and focused on the goal - the attainment of a degree. They provide a counter to the pioneering tone of the builders of the institution, the administrators, who imbued with the desire to fulfil their apartheid mission failed to see the humiliation and resentment that students felt. Even though Manu relegates the university there as "substandard" and lacking "history", it would be wrong to say that Salisbury Island has no meaning. It shaped Jasu and Manu. They found each other on the island thus making it a crucial site of memory.

Primilla Bhikha (nee Lalloo, born 1956) would also be bound for Durban, ${ }^{52}$ but her destination would be to the University of Durban-Westville already two years old when she got there in 1974. Primilla who lived in Claremont, had already felt the impact of apartheid during her primary school days. She explains:

\footnotetext{
${ }^{51}$ Govinden, "Remembering 'Salisbury Island'”, 53-62.

52 Interview with Primilla Bhikha by Uma Dhupelia-Mesthrie, 30 January 2010.
} 
I ended up going to three primary schools and this all had to do with the government of the day. The first primary school I went to was Newlands Primary which I attended until Standard 2 and at the end of that year the school was ordered to close because of the group areas situation. Newlands was declared a white area so that school closed down. My Standard 3 year was done at another school also at Newlands called St Andrews Primary School. At the end of my Standard 3 year that school then was also closed down. The third primary school which I attended was Stephen Reagan Primary School in Main Road Claremont. I attended Standard 4 and 5 there and, interestingly enough, at the end of my primary schooling that school also closed down.

These schools were predominantly attended by coloured children and as group area proclamations became effective their fate was sealed. Primilla then went on to Livingstone High School. Claremont itself underwent significant changes from the 1960s to the 1970s.

Declared a white group area, her father had to shut down his shoe shop but managed to stay in his house challenging group areas inspectors on a yearly basis. Primilla relates how the neighbourhood transformed:

We had neighbours who were coloureds and there were obviously Moslems and we got along with all of them but gradually all those families - and most of them were renting properties - they gradually started moving out. And so the colour of the neighbourhood changed because as those families moved out white neighbours moved in. By the time I reached high school, almost all the neighbours were white. Everything had changed which also meant that we were one of the few Indian families left in that area ...

She explains the decisions faced on completion of her matriculation:

I was then left with two choices. If I wanted to go to university and depending on what I wanted to do I would probably have to leave home. Otherwise I would stay at home and not be able go to university. So that was the big decision. And, I think for me, I was fortunate in that my parents were willing to send me away from home in order to study at university which I think a lot of my other girl friends were not quite so lucky. ... In the early seventies there were still many Indian families and, in particular, the Gujarati families where the parents were not happy to send their daughters away from home to study. So I think many of the girls at that time were denied the opportunity to go to university simply because they would not have been able to attend university here in most cases and their parents wouldn't send them away. I consider myself fortunate at that time.

She wanted to study pharmacy and since this was offered at the University of DurbanWestville she would have to go there. I have to ask Primilla if she felt any resentment at having to go to Durban, for she does not volunteer this. She replied: 
I think the resentment really came from that fact that I'd lived so close to UCT here in Claremont and UCT was virtually a stone's throw away from our home but I wasn't able to attend that university. And, you know, I, in fact, ended up going to university which was far away from home not knowing what to expect over there. So I think that if there was any resentment that was the fact there was an additional expense incurred in having to study so far away from home. But then there were many other students, I suppose, in similar situations.

She describes the travel logistics:

Initially, my very first trip to Durban was on a train and there were other students who were also on that train. So I immediately made friends with people who were going there for the very first time. I wasn't the only one. And on that train I met some of the senior students who knew the ropes and who had been travelling up and down for several years so I think they were a good source of information and guidance about what to do when you got there and that sort of thing. I think that helped quite a bit and the train ride being as long as it was meant that we had to keep ourselves occupied. I think it took two days and one night on the train. So I had a lot of time to talk to other people who were on the train and so ... by the time we got to Durban I felt a lot more confident about what to expect.

One of the seniors she met was Siraj Desai and he was able to offer much advice. Durban posed an encounter with Indianness to a larger extent than she had known thus far. Her Indianness would have had been limited to Gujarati school, to her father's passion for Indian art, the food at home, and the religious and cultural meetings at the Mitra Hall in Mowbray, but it was Claremont that had shaped her. Durban was "different", "slightly daunting" and "a little exciting." Primilla was fortunate in that her brother had already preceded her to Durban as a medical student. After her first year in the hostel, she and her brother shared a flat with three other students and they managed the cleaning and cooking themselves. Thereafter, over the next four years, she ended up boarding with various people. She speaks about her hostel experiences:

It was an interesting experience I think living in close proximity with all these girls for the first time in my life. Also girls who came from very different backgrounds, many of them from very privileged backgrounds and that was a bit of an eye opener for me. But all the same l'd say it was a good experience. The fact that you lived on your own, you had to make your own decisions, decide on how you were going to do things and just, generally, looking after yourself. I think that was the positive part of that whole experience.

I think the other positive part that came out of it was the sense of camaraderie that you felt. Although we all came from maybe different religious backgrounds, there was a common element and something that we could all identify with each other is the fact that we had Indian roots and I think that binds people together. And so I 
think that was the very positive thing about going to an ethnic university like UDW. I'm not sure that I would have had that experience at any other university. But all in all it was certainly a worthwhile experience.

In her second year she switched from BSc to law and in 1979 completed her LLB, becoming the first Gujarati female lawyer in Cape Town. Knowing that white legal firms would not employ her to serve her articles, she obtained a list from the Law Society and secured placement at a black legal firm. ${ }^{53}$ Following her marriage to Bharat Bhikha, she settled in Rylands. Though she had lived in Claremont, Rylands did not prove too difficult to settle into as they knew lots of people and family here.

Primilla's narrative is one that demonstrates how apartheid encroached steadily through all aspects of life from schooling, to university and to place of residence. Yet it also shows some ease with Indianness. Its significance lies in her account of the journeys young women like herself had to take to get to Durban. Several times she uses the word 'positive' and that is how she has made meaning of her experiences.

\section{Avoiding the Indian University}

Betty Govinden provides a sensitive insight into those, like herself, who went to Salisbury Island. She observes: "We were forced to attend these institutions, and never failed to remind everyone that we did so under continual sufferance." Importantly, she argues, "We were sometimes tempted to deny this part of our lives, especially when those who went to the prestigious white universities ... often treated us as lesser beings. The words "inferior" and "second class" were not infrequently used in relation to places such as Salisbury Island." ${ }^{54}$ Surendra Bhana, who went to the University of the Witwatersrand in 1960, a year before Salisbury Island was started, provides a sharp contrast to what those attending Salisbury and Westville felt:

I felt special being a student at Wits. It helped to build my confidence. I bragged about being a Wits student. It gave me status, and when I could afford it, I bought myself a Wits blazer. Its zebra-stripes in a screaming blue colour got you noticed. The neatly-trimmed lawns at Wits provided me with an escape from the squalor of

\footnotetext{
${ }^{53}$ I use the term black to include Indians, coloureds and Africans.

${ }^{54}$ Govinden, "Remembering 'Salisbury Island'”, 52-53.
} 
Fietas ... I learnt a lot in my three years at Wits. But it distressed me that the lecturers knew so little about people of colour. ${ }^{55}$

This section dwells on Cape Indians who avoided the Indian university, and the narratives provide a broader understanding of higher education and the struggles faced by such students. While it is true that a 'them' and 'us' developed, and the ethnic university led to deep feelings of inferiority, it is hoped, that the sharp divide traditionally made between those who went to the Indian university and those who did not is somewhat narrowed by these narratives. There was no escaping permits - if one left Cape Town for Durban one secured a permit to travel; if one stayed in Cape Town then, a permit to secure entrance to a white university was needed. While they did not feel insecure about the quality of their education, those at UCT would also find it hard not be conscious of their race and differential treatment. For some, the experiences post-university would also be marked by discrimination in places of employment, irrespective of whether one had a degree from an Indian university or a university with 'history' like the UCT.

Damyanti Chagan (nee Chavda, born 1941) grew up in the southern suburbs of Mowbray where her father, Baber Chavda, had a fruit and vegetable store. ${ }^{56}$ She attended the local schools in Mowbray, Newlands and Claremont: St Peter's Church School, Newlands Primary School and then Livingstone High School. Mowbray was a residential area that was mixed and UCT was but a few minutes away. The first of her four siblings to matriculate in 1959 she faced many difficulties. She notes how they were "clueless" about university applications and the new higher education law. Her father was determined that she become a doctor. While she applied for medicine at UCT, she failed to apply for the necessary permit and wasted that year. The second year, she applied for a permit, but was refused. She says:

... we tried and we couldn't just get a permit. My dad tried every possible means to get a permit and every time they said I have to go to Salisbury Island ...but I was still determined. I had my heart set on a university education ...

There was no question about her being sent to Durban so, in the meantime, she went for sewing classes and helped in the shop.

\footnotetext{
${ }^{55}$ Suryo [S Bhana], 'Klap Hom: Somebody Should' (unpublished memoirs, privately held, 2012), 28-30.

${ }^{56}$ Interview with Damyanti Chagan, by Uma Dhupelia-Mesthrie, 9 April 2010 and additional information by telephone, 3 January 2012.
} 
In 1962 she realised her dream and registered at UCT. The family had sought the assistance of Hoosein Parker, a Cape Town City Councillor and he managed to "pull strings" so that she secured a permit to do a social sciences degree. She also took additional science subjects so that if she passed she could then apply for second year medical school. ${ }^{57}$ She, however, soon dropped the science subjects and four years later qualified as a social worker.

Damyanti, when asked, had little to say about social discrimination unlike Archie Mafeje, who would become a celebrated anthropologist, and who studied at UCT in the late 1950s as did Philip Kgosana, who later became famous for leading the march from Langa to the city in 1960. As an African minority in this elite world, they experienced social discomfort. Mafeje relates how when he went for a swim this so unsettled white students that the pool was drained after his use. Kgosana found UCT to be "awful"; he singled out professors who made disparaging remarks about Africans. ${ }^{58}$ Damyanti on the other hand, was one of four Indians in the Social Science Faculty and got on well with her fellow students. If there was any discomfort this came when students had to visit organisations on observation excursions. Some of these organisations, when, being informed by the lecturers that their class was racially mixed, objected and insisted that the different race groups make separate visits. This Damyanti refused to do; she and her fellow Indian students did not go on these visits. She also recalls that when they completed their course, the students looked for a restaurant where they could all celebrate. After much difficulty, one restaurant agreed to have them all. In the end she and her fellow Indian students discussed it and did not go. One main reason was that they did not know how to eat with forks and knives! This adds another dimension to early socialisation between whites and others.

Finding employment as a social worker was the next hurdle - as she says "I couldn't work in a factory as an industrial social worker. Because I'm an Indian I couldn't oversee coloureds." She found a position at Child Life Organisation in Wynberg. She recalls that the social workers of different races sat in one office. However, when a white person came to consult

\footnotetext{
57 She points to two Indian students who successfully pursued this route in 1961 and who made it to second year medical school.

${ }^{58}$ Bank, Archie Mafeje, 17.
} 
a white social worker she had to leave the room so that she could not hear the details of white life. Though one could not get a position at Groote Schuur Hospital, ${ }^{59}$ she was employed at Somerset Hospital as a replacement for a social worker whom she knew who went on leave. She found it a "dead end." Instead of social work, she found herself doing work akin to occupational therapy and lots of paper work.

Durban was never a possibility for her for further studies or work. As she says "I had no one I knew there and I rather go to India than go to Durban actually." And so she went to India in 1968 where she secured a Master's degree at the Tata Institute of Social Sciences in Bombay (now Mumbai). On her return in 1970, she found work with the Robert Nurok Day Hospital in particular, working at the hospitals in Langa and Bonteheuwel. Later, after her first child she also worked for the Building a Better Society in Kewtown on the Cape Flats. While working in the townships posed no difficulties initially, for her "white coat" was respected, after the 1976 unrests she found it hard to carry on. She ultimately joined her husband, whom she had married in 1973, in his business.

Damyanti's narrative is marked by the determination to secure a university education and not in Durban. Her energies were devoted to avoiding Durban and persevering with her goals. She could live in Mowbray with her family and travel to UCT with little difficulty. The permit was a treasured document obtained after some difficulty and not without some influence. While she rejected Durban and a separate education at an Indian university, Damyanti's childhood was also rooted in a strong sense of being a Gujarati. Her father was one of the officials in charge of the local temple and hall in Mowbray and she also went on to complete Gujarati school up to standard seven. When it came to a career and education, the family wanted the best and separate education in a ghettoised fashion with a daughter away from home was not going to happen. Yet she did not escape apartheid's restrictions completely as was seen in her work experiences. After her marriage, she like most Indians had to live in the designated group area. Once group areas restrictions were lifted, in the early 1990s, she left Rylands and currently lives in Three Anchor Bay in an apartment

\footnotetext{
${ }^{59}$ Dr Mahate points out that doctors who qualified had to leave Cape Town and go to Natal. He, for instance, went to Edendale Hospital. Interview, 17 December 2009.
} 
overlooking the Atlantic Ocean. She visits Rylands occasionally to purchase Indian vegetables, visit family and attend the temple for special occasions.

Latifa Omar (born 1949) was the second youngest of siblings who numbered twelve in total, not counting two others who died in infancy. ${ }^{60}$ Her father, Mohamed Omar, died when she was three years old and her mother, Ayesha Omar, and the elder siblings kept the household going. They moved homes several times from Salt River to Observatory to District Six and then, finally, to Rylands. While the elder male siblings bought fruit and vegetables wholesale for redistribution to smaller traders, her brother, Dullah (born 1934), who was the sixth of the children was the first to go to high school and to university. He obtained a BA LLB from UCT in 1957 and his younger siblings followed his example. Two of them became doctors, two librarians and one a teacher. Latifa went to Kipling Street School in Salt River, then to Chapel Street Primary School in Woodstock and finally, to Trafalgar High School. She remembers the spirit of growing up in District Six and also notes the closeness of the Kanamia Muslims who lived there - the Gujarati Muslims of whom they were also a part.

After matriculating in 1967, Latifa wished to follow in her elder siblings' steps and become a doctor. She took the route via a BSc for which she registered at UCT. She recalls that the goal was to avoid going to Durban. She cannot remember the exact details of the motivation for her permit, but notes that it highlighted the quality of education that she would receive at UCT and family considerations such as having to leave home with no support in Durban. She recalls an inspector calling at her home to verify the details of her application. He inspected the house and sought interviews with her mother and other members of the family. Latifa was granted a permit. However, her first year at UCT did not go well as she soon realised she was not cut out for science. She spent another year working before revisiting her desire to study again.

This time she decided on a BA and a permit to UCT was unlikely to be given. She explains : "because BA was offered at Durban-Westville they very seldom would give people

\footnotetext{
${ }^{60}$ This is based on an interview with Latifa Omar by Uma Dhupelia-Mesthrie, 15 February 2010 and telephone conversation, 28 December 2012 when additional information and clarity was obtained.
} 
permission to study at a resident university here so for that reason I didn't we didn't even bother applying because they were very strict and sometimes arbitrary." No reasons for refusals or acceptances were ever given. She settled down to study through correspondence with UNISA and worked "systematically" almost as if she was at university. "It was more a matter of blocking out your time stating right today you working from 10 o' clock till 1 o'clock and then 3 o'clock till six o'clock." She obtained the full support of family and notes her elder sister would not ask her to do any housework if she was studying. This was how she obtained her BA. In 1976, she registered at UCT for a higher diploma in librarianship. She cannot remember details about her permit for this application. In the 1970s there was some relaxation on issuing of permits especially for post-graduate study. ${ }^{61}$ On qualifying, she worked for the municipality's libraries and ultimately at UCT libraries. In the democratic era she served on the Cape Town City Council. Though retired now, she does lots of volunteer work and chairs the TRA with which she has been associated from its inception. Rachmat Omar (born 1951), Latifa's younger sister and the youngest of all the Omar siblings, also went to the Kipling Street School in Salt River and to Trafalgar High School. ${ }^{62}$ She notes how five of her older siblings had all studied at university so by the time she completed her matriculation in 1968 "it was fairly well established that I could go and study. There was lots of support from my older brothers and sisters for us to study..." Rachmat wanted to be a teacher - her route was the BA and then a postgraduate teacher's diploma. There were hurdles such as the need for a permit to study at UCT and the fact that her mother was not going to let her leave Cape Town. She first started working at city libraries and studied through the initiative of SACHED, founded in 1959 to provide an alternate education to that being controlled by the state. It provided access to the advanced general certificate in education and degree studies through the University of London. SACHED's rationale was:

Black students studying through London University would gain a degree of high academic standard which would be internationally recognised. In this way their education would be free of the ideology of 'ethnic education' and also free of the stigma of inferiority. ${ }^{63}$

\footnotetext{
${ }^{61}$ See Oosthuizen et al, Challenge to a South African University, 73.

62 Interview with Rachmat Omar, 15 January 2010.

${ }^{63}$ EP Nonyongo, "The South African Committee for Higher Education (SACHED)", accessed on 28 December 2012 from www.uni-oldenburg.de/zef/cde/support/readings/nonyo98.pdf, 2.
} 
The numbers of Black students who enrolled for this were few in comparison to those who were at universities. Nonyongo points outs that in 1960 there were 4400 black students at universities (1901 African, 1602 Asian and 878 Coloured) and that year SACHED had but 80 students. While SACHED provided a support system giving advice and study materials, long distance study with the University of London was difficult. Only 4 students managed to secure degrees by 1971, which prompted a shift by SACHED to promote study through UNISA. ${ }^{64}$ Rachmat managed to complete her A levels and started the first year BA. However, once she secured a bursary to study in England, the SACHED experiment ended.

The idea of her travelling to England provoked some discussion in the family. "So after a lot of debate in my family my mother finally agreed that I could go ... For girls to go so far away from the family was not really accepted at that stage. Dullah played quite a big role in convincing my mother that it would be fine for me to go." She spent four years in England acquiring a BA from the University of Hull and then a postgraduate certificate in education at the University of London.

Rachmat returned in 1976 to a city that was in turmoil especially in the Black schools and townships. For the next decade and more she taught at high schools in the coloured group areas: Bridgetown High School, Bonteheuwel High School and Groenvlei High School. Though Rylands High School had newly opened in 1976, the idea of an Indian only school was a foreign concept to Rachmat and she chose instead to apply to the Coloured Affairs Department. She notes that the Department of Indian Affairs was eager to secure a list of the names of Indian teachers and students teaching and studying at coloured schools but fortunately many principals refused to do this and she thus avoided forced allocation to Rylands High school.

Rachmat was a founding member of the TRA and during the turmoil on the Cape Flats she was detained in 1985 . Influenced more by unity movement politics, she and other TRA members played some role in opposing moves when those organising the anti-South African Indian Council movement entertained the idea of forming a Cape Indian Congress. The Natal Indian Congress tradition of organising as Indians was thus rejected. Blacklisted from

\footnotetext{
${ }^{64}$ Nonyongo, "SACHED", 2-5.
} 
teaching, Rachmat moved to Johannesburg where she worked for Congress of South African Trade Unions (Cosatu) for fifteen years and studied at the University of the Witwatersrand. She currently works at the University of the Western Cape at the Centre for Adult and Continuing Education. Her narrative is one of constantly rejecting the Indian box that apartheid tried so hard to place her in and also that of pushing the boundaries of what young Muslim women could do.

Bharat Bhikha ${ }^{65}$ is of a much younger generation than Damyanti and also a few years younger than Rachmat and Latifa. His entry into tertiary education was in 1974. Born in 1956 he grew up in Walmer Estate and went to Walmer Preparatory School. For high school he went to Harold Cressy in District Six, a school with predominantly coloured students, among them being Trevor Manuel, and a highly politicised teaching body. Bharat remembers political protests in the city in the 1970s which his school and the nearby Trafalgar High School participated in the early 1970s. When Walmer Estate was declared a coloured group area, his father purchased a home in Rylands which was within easy reach of his laundry business in Athlone Industria.

Bharat was clear that he was not going to go to the University of Durban-Westville, for he wanted to study architecture which was not offered there. He applied for a permit to study at UCT:

I remember in those days the regional representative in Cape Town was a Mr de Jager [the regional representative of Indian Affairs] and Mr de Jager was somebody who, I think, many of the Indian families had gotten to know over the years because he was somebody you needed to know in order to get things done and I remember going to his office to go and sign the forms - the application forms and the permit forms etc - and we had to wait in anticipation whether I was going to get the permit.

And when I was accepted at UCT then I remember going into Mr de Jager's offices and walking out there very proudly at that time with my permit ... to attend UCT.

For Bharat that permit was a major document opening up opportunities. His years at UCT were relatively trouble free. He says:

The .... thing I remember in my first year [is] there were only five people of colour. And it was never confirmed and I never pursued the matter further than that -1

\footnotetext{
${ }^{65}$ Interview with Bharat Bhikha by Uma Dhupelia-Mesthrie, 30 January 2010.
} 
believe that there was a sort of unofficial quota that they had operating at the time that they would in that particular course accept only five students of colour every year.

The fourth year of his course was a practical year. He applied to numerous architectural firms without success. One white firm indicated that it did not take on students, Bharat subsequently found fellow white students employed there. Eventually, he was employed at a newly established black firm. Later, when he sought a position in Johannesburg, accommodation was the real challenge:

It wasn't easy my first three or four weeks. I stayed with relatives in Lenasia and everybody travelled into town so you'd get up and it was pitch dark outside and it was cold and when you come home in the evening it was the same ... I must say, it wasn't a nice existence but you know everybody in Lenasia did that.

Bharat completed his degree in 1980 and today is a manager of operations for the Airports Company at Cape Town International Airport where he oversees planning and project implementation. He and his wife Primilla are well settled in Rylands. He observes that he is "comfortable" here, citing a long period of residence, the existence of various cultural facilities, and "living amongst people who have similar traditions [and cultural] practices ..."

\section{Conclusion}

This article has highlighted life stories of individuals from the Cape who embarked on tertiary education at the height of apartheid. The Extension of University Education Act of 1959 would impact on them and some had to go to the Indian university, some navigated the permit system, others took the lifeline that SACHED extended, and some went overseas. While undoubtedly those who went to Durban had a segregated education which symbolised and conferred a stigma, this collection of narratives seeks to narrow the differences that are suggested between those who went to other universities and those who went to Salisbury Island. All of them were affected by apartheid and made sacrifices. Young women travelled far from their homes to Durban, to India or to London and they were pioneers in many ways. Avoiding Durban could also mean sitting at home, studying through correspondence and missing out on a university life. 
Apartheid brought a range of permits and created differences in experiences. Yet, while allowing entry to an established white university, it entailed some humiliation in the very fact that an application was necessary. The permit system is one that deserves further study. To what extent did people feel compromised by applying for it? What did those on Salisbury Island think of the permit students? Some interviewees search for the positives in their experiences without lamenting and emphasising the obvious discrimination they experienced. Several of those interviewed would be the first in their families to receive a university education and others had their paths made easier by siblings. Particularly striking are the efforts and determination of the women interviewees to secure a university education.

What these narratives suggest on the whole is that to assess the impact of the 1959 Act one needs to place it within the broader context of apartheid that takes into account classification as Indian, group areas removals and job restrictions. For most of these individuals, university education was one major experience of discrimination and denial of freedom of choice. In terms of fostering Indianness, the Indian University at Salisbury Island had, however, but a small role to play for Cape Indians. It represented a small number of years in the total life experience of these individuals. Its main impact was to create an Indian professional class. Nationally, the number of Indian professionals would far exceed coloureds and Africans. ${ }^{66}$ That several siblings from a family attended university at the same time was a sign of the growing demand for higher education. The establishment of the group area in Rylands would have a far greater impact on Indianness as some of these narratives suggest, ${ }^{67}$ but some fought strongly to break through the Indian barrier, a subject that will be addressed elsewhere. ${ }^{68}$

\footnotetext{
${ }^{66}$ Dhupelia-Mesthrie, From Cane Fields, 19.

67 See for instance the burst in cultural activity on relocation to Rylands as discussed in Uma DhupeliaMesthrie, "Cultural Crossings from Africa to India: Select Travel Narratives of Indian South Africans from Durban and Cape Town, 1940s to 1980s", South African Historical Journal, Vol. 64, No.2, June 2012, 307-9.

${ }^{68}$ This is part of my greater project on Cape Flats Histories of which the history of Rylands is a part.
} 